УДК 347.1

https://doi.org/10.34142/23121661.2019.30.07

orcid.org/0000-0002-1925-8357

(C) Альошин B.В., 2019

\author{
В.В. Альошин
}

\title{
ГЕНЕЗИС ЦИВІЛЬНО-ПРАВОВОГО ІНСТИТУТУ ЗАВДАТКУ
}

\section{Aloshyn \\ GENESIS OF CIVIL LAW INSTITUTE DEPOSIT}

\begin{abstract}
Анотація. У статті автором було досліджено способи забезпечення виконання зобов'язань в історичному аспекті. Автор прийшов до висновку, що інститут забезпечення виконання зобов'язань завдячує своїм походженням праву Стародавнього Риму, де було створено струнку систему таких способів. Перші згадки про забезпечення виконання зобов'язань можна віднайти ще в Уложеннях Юстиніана 529 р. Визначаються види зобов'язань, що можуть бути забезпечені завдатком. Установлюється співвідношення завдатку та авансу. Аналізуються правові наслідки порушення та припинення зобов'язання, забезпеченого завдатком. Звертається увага на наявність прогалин у цивільному законодавстві щодо регулювання завдатку та пропонуються шляхи їх заповнення шляхом внесення відповідних змін до Цивільного кодексу України.
\end{abstract}

Ключові слова: забезпечення виконання зобов'язань, завдаток, функції, правова природа.

Аннотация. В статье автором были исследованы способы обеспечения исполнения обязательств в историческом аспекте. Автор пришел к выводу, что институт обеспечения исполнения обязательств обязан своим происхождением праву Древнего Рима, где была создана ровная система таких способов. Первые упоминания об обеспечении выполнения обязательств можно найти еще в Уложении Юстиниана 529 г. Определяются виды обязательств, которые могут быть обеспечены задатком. Устанавливается соотношение задатка и аванса. Анализируются правовые последствия нарушения и прекращение обязательства, обеспеченного задатком. Обращается внимание на наличие пробелов в гражданском законодательстве в части регулирования задатка и предлагаются пути их заполнения путем внесения соответствующих изменений в Гражданский кодекс Украины.

Ключевые слова: обеспечение выполнения обязательств, задаток, функции, правовая природа.

Abstract. In the article, the author explored ways to ensure the fulfillment of obligations in the historical aspect. The author came to the conclusion that the institution for ensuring the fulfillment of obligations owes its origin to the law of Ancient Rome, where a harmonious system of such methods was created. The first mention of securing compliance can be found in the Justinian Code of 529. The types of obligations that can be secured by a deposit are determined. The ratio of the deposit and advance is established. The legal consequences of the violation and the 
termination of the obligation secured by the deposit are analyzed. Attention is drawn to the presence of gaps in civil legislation regarding the regulation of deposits and ways to fill them by introducing appropriate changes to the Civil Code of Ukraine are suggested.

Keywords: provisionoffulfillmentofobligations, deposit, functions, legalnature

У різні історичні періоди забезпечення виконання зобов'язань відігравало важливе значення у сфері суспільних відносин, що свідчить про багатовікову практику. Серед інших видів забезпечення виконання зобов'язань у цивільному праві 3 часів виникнення i до теперішнього часу завдаток пройшов шлях певних змін і перетворень та посів гідне місце. Чіткої відповіді на запитання стосовно часу та місця виникнення завдатку немає, незважаючи на велику кількість наукових досліджень, а щодо походження завдатку науковці з цивільного права мають різні погляди. Близькосхідне походження завдатку («arra») зафіксоване в юридичній літературі [1, с. 374; 2, с. 291]. Такої ж точки зору був і Є.С. Куліков, який вказував, що завдаток з'явився в цивільному (торговому) обігу країн Близького Сходу як звичай, що закріплював договір між сторонами та не дозволяв їм (без відповідальності) відмовитись від договору [3, с. 2]. Про єврейське і грецьке походження завдатку зазначає М.Ф. Єрмошкіна. Завдаток у Греції був конститутивним елементом правочину, згідно із загальноприйнятим правилом: договір набирав сили після передачі завдатку, якщо він ним повинен був забезпечуватися [4, с. 14]. В історії розповсюдження й міжнародного застосування договірних правочинів, завдяки цьому способу закріплення договірного зобов'язання, дослідники давнини приписують вкрай важливе значення. Релігійні обряди були покладені в першооснову завдатку. Можливо, матеріальний тягар витрат у цих обрядах падав на особу, яка не виконала взяте на себе зобов'язання, з якими укладення договору було пов'язане. Це була лише початкова стадія для історії виникнення та подальшого розвитку завдатку. Лише тоді, коли стає окремим актом, не пов’язаним $з$ обрядами «аrra», набуває самостійного значення та широкого розповсюдження. Завдаток з часом став звичайним актом вручення реальної цінності тому, хто прийняв на себе виконання зобов'язання [5, с. 77-78]. Певна сума, яку виплачувала одна зі сторін іншій під час укладення договору або незабаром після цього у рахунок майбутніх платежів і на підтвердження укладеного договору, йменувалася, за афінським правом, завдатком. Сторона, яка не виконувала зобов'язання, яка давала завдаток, його втрачала; якщо ж сторона, яка отримала завдаток, була винною в невиконанні договору, вона виплачувала потерпілій стороні подвійну суму завдатку [6, с. 43]. На думку I. Б. Новицького, завдаток за своїм етимологічним значенням є «заздалегідь дане», «дане наперед» [7, с. 240]. В елліністичний період на грецькому Сході значення завдатку було настільки великим, що правочини про купівлю-продаж, які не супроводжувались завдатком, могли бути анульовані із звільненням кожної зі сторін від обов'язку відшкодовувати збитки [8, с. 231]. Зазначені 
аспекти проаналізовано в працях Ч. Н. Азімова [9, с. 10-12], М. І. Брагінського та В. В. Вітрянського [10, с. 838-840], Б. М. Гонгала [11, с. 45-48], О. С. Йоффе [12, с. 125], Г. Ф. Шершеневича [2, с. 291-293]. До часів існування римського приватного права, наголошується науковцями, першими документально закріпленими згадками про завдаток відносяться, зафіксовані в тогочасних правових працях римських юристів - Гая Юлія Цезаря, Цервідія Сцеволи, Юстиніана. Перший поштовх до розвитку та широкого розповсюдження завдатку дала ще тоді римська юриспруденція, створила досить струнку та чітку систему правових засобів забезпечення зобов'язання, в яких, зокрема, почесне місце посів завдаток. Аналізуючи систему римського права щодо забезпечення виконання зобов'язань, Л. В. Смельянова визначала існування у класичному римському праві таких засобів забезпечення, як застава, завдаток, штрафна стимуляція, порука та інші, що відрізняються за спрямованістю, характером дії, суб'єктами тощо. До реальних (речових) засобів забезпечення виконання зобов’язань відносились завдаток та застава у римському праві [13, с. 8-9]. Грошова або інша цінна річ відповідно до норм римського приватного права, визнавалась завдатком («arra»), яку одна сторона - боржник (найчастіше покупець) - дає другій стороні - кредитору (продавцеві) у момент укладення договору [14, с. 364]. Стрімке розширення цивільного обороту, розвиток торговельних, зобов’язальних, речових відносин між громадянами стали істотними передумовами, пов'язаними із зародженням завдатку як складової зобов’язального права. Кодекс (Уложення) Юстиніана I від 07 квітня 529 р. став одним із перших кодифікованих актів, у якому введено поняття завдаток («arra»).. Зобов’язальні відносини між покупцем та продавцем вже тоді було визначено у цьому документі, а також розтлумачено, що до факту укладення договору про купівлю-продаж прирівнювалась домовленість про передачу певної грошової суми (завдатку). Договір вважався укладеним, якщо було досягнуто згоди сторін щодо ціни за товар, ïi справедливості та факту самої згоди, визначено в уложенні Юстиніана I., та ні одна зі сторін не мала права ухилятися від його виконання. Завдаток був одним із двох винятків у цьому загальному правилі. Завдаток (визначена грошова сума), який покупець вносив у рахунок оплати купленої речі, не підлягав поверненню, та потім, якщо від договору він ухилявся, то поверненню не підлягав, а продавець здійснивши аналогічне порушення, був зобов'язаний повернути подвійну суму завдатку покупцеві (так було у законодавстві Юстиніана). До факту укладання договору про купівлю-продаж прирівнювалась домовленість, яка складалась між сторонами про «arra» [12, с. 124-125]. Також за усною згодою між сторонами в римську епоху міг передаватися завдаток. Факт укладення договору мав підтвердити, підкріпити arraconfirmatoria у класичну епоху. Одна сторона, найчастіше покупець, іноді наймач, вручав іншій стороні грошову суму або цінність (золоті прикраси) при укладенні договору [1, с. 373-374]. Роль доказу 
укладення договору, на думку Цезаря, відігравав завдаток, хоча це не означало, що без передачі завдатку договір втрачає своє юридичне значення.

До того ж Цезарем був визначений акцесорний характер договору про завдаток, зокрема він писав: «Те, що передається як завдаток під час купівлі, не має такого значення, якби без завдатку договір не приводив до результатів, але слугує для того, щоб точніше могло бути доведено, що сторони домовилися про ціну» [15, с. 291]. І.С. Розенталь, коментуючи вислів Гая Юлія Цезаря стосовно того, що дане у формі завдатку $\epsilon$ доказом укладеного договору купівлі-продажу, зазначав: «Це не означає, пише Гай в іншому місці (D.18/1/35), що без передачі завдатку договір не має юридичної сили, але завдаток видається для того, щоб був наочний доказ укладеного договору» [1, с. 373-374].

Отже, для підтвердження факту укладення договору в класичну епоху завдаток частіше передавався у вигляді речі або цінності. Річ, яка передавалась іншій стороні саме в значенні завдатку, а не застави у класичну епоху, на думку Є.С.Кулікова, після виконання зобов'язання поверталась власнику. Оскільки застава у випадку невиконання зобов'язання була засобом забезпечення майнових витрат кредитора, а завдаток - ні [3, с. 3]. На знак того, що договір справді укладений, одна сторона надавала другій стороні якусь річ або невелику суму грошей відповідно до існуючого у класичному римському праві звичаю (при договорах купівлі-продажу). Ця сума грошей або річ називалася завдатком. Конфірмативне значення мало надання завдатку в цьому випадку. Сторона, яка надала завдаток, мала право відмовиться від договору, залишаючи завдаток, але це сталося дещо пізніше, коли завдаток набув другого значення. Якщо контрагент поверне подвійну суму того, що отримав (завдатку), то в такому разі він міг відмовитися від договору. До суми відповідного платежу завдаток зараховувався, якщо договір було виконано [17, с. 296-297]. Примус боржника i кредитора до виконання зобов'язання - «arrapoenalis» було передбачено у 528p. Юстиніаном, і 3 того часу завдаток набув штрафної функції. Покупець втрачав завдаток, якщо відмовлявся від виконання договору купівлі-продажу, який ним був забезпечений. Продавець повертав у подвійному розмірі завдаток, якщо відмовився від виконання договору. Супроводжуючи основний договір, римський завдаток завжди був у якості додаткового договору [1, с. 364]. Обмеження розміром, що дорівнює сумі завдатку, можливе, на думку юриста Цервідія Сцеволі, якщо сторони домовились про відповідальність особи, яка відступила від договору, таким чином, завдаток відіграє роль відступного - «arrapoenitentialis». Сума завдатку зараховувалась у рахунок належних платежів тільки тоді, коли операція розвивалась нормально, і договір виконувався сторонами [1, с. 373-374]. До останнього юстиніанського періоду римського права (VI ст.) романісти відносять зародження завдатку «arrapoenitentialis» [16, с. 19-20]. Не завжди вказує на існування самостійного правового інституту застосування того чи 
іншого терміна, таку позицію щодо розвитку завдатку в римську епоху висловив Д.Ю. Полдніков. За традицією щодо першого часткового платежу в рахунок покупної ціни вважали «завдатком» римські юристи у I-III ст., який, крім назви, нічим не відрізнявся від часткового виконання зобов'язання [18, с. 30-37].

Грошовою сумою чи будь-яким іншими речами, що видавались 3 метою закріплення договору, К. Н. Анненков характеризував завдаток, даючи оцінку римським правом. Інколи завдаток був доказом укладання договору, а інколи засобом примушування до укладання договору, отже, завдаток був двозначним [19, с. 214]. Залежно від домовленостей між сторонами у римському праві набув значення i доказу укладення договору, та відступного, та штрафу. Незважаючи на те, що окремі нариси та висновки про завдаток знайшли своє відображення в юридичних пам'ятках певних епох, дослідження правової літератури дає підстави констатувати, що на деякий період завдаток виходить 3 широкого вжитку на тривалий час [20, с. 52]. Від економічних та політичних умов та потреб суспільства в Україні, які формувалися у певний період розвитку, дало підстави для висновку, що вони мали вплив на рівень правової регламентації відносин, пов'язаних із завдатком. Завдаток не був видом забезпечення виконання зобов'язань, проте застосовувався у так званих зобов'язальних відносинах, пов'язаних із укладенням договорів особистого найму особи відповідно до зведення законів «Руська правда», які були найпершим та найважливішим джерелом давньоруського права XIXIII ст. «Закупный наймит», який не побажав залишатися у пана і звернувся до суду, міг отримати свободу, повернувши феодалу «вьдвое завдаток», за церковним законом «Правосуддя митрополиче», що було фактично неможливо, оскільки пан i визначав розміри цього «завдатку» [21]. Тобто, за можливість наймита відплатитися від статусу феодальної залежної особи - холопа, розглядалась як завдаток у вигляді грошової суми у давньоруських пам'ятках, а не за річ або майно, які були куплені чи орендовані. Період, який припав на XIV-XVII ст., перебування українських земель у складі Великого Князівства Литовського і Речі Посполитої став важливим етапом для розвитку зобов'язальних правовідносин, зокрема і завдатку [22, с. 61]. На землях Польського Королівства (1387-1567 рр.), Речі Посполитої (1569-1795рр.), до складу яких входила територія Галичини та Західного Поділля, на думку О.С. Поповича, почали активно оселялися й вірмени. Понад 70 вірменських громад було утворено на українських землях у XIII-XVIII ст., яким було надано адміністративноправову автономію [23, с. 3]. В укладанні найбільш поширених цивільноправових договорів спостерігалася активна участь вірмен із самого початку переселення як у здійснені внутрішньої, так і зовнішньої торгівлі. Значна частина Вірменського статуту 1519 р. була присвячена зобов’язальному праву, враховуючи те, що основними заняттями вірмен були ремесло й торгівля. Зобов'язання щодо виконання всіх його пунктів сторони брали на себе, за 
умовами статуту, укладаючи договори майнового характеру. Після дотримання сторонами чітко визначених у ній зобов'язань правочин вважався виконаним. Товари, ціна, строки, місце та час виконання угоди відносились до істотних умов договору. Порукою та завдатком забезпечувалось виконання зобов'язань. Присутність свідків була необхідною умовою при укладенні договору. Поняття усної угоди не було передбачено вірменським статутом. Відомості щодо угоди про ціну та суми завдатку в ньому відсутні. На теренах України розвиток вірменського зобов'язального права був зумовлений завдяки безпосередній участі вірмен у торгівлі. [24, с. 31]. Розвиток інституту завдатку базувався на фундаменті, який був закладений «Руською Правдою» XI-XII ст. та звичаєвим правом за часів дії Литовських статутів, оскільки на той час застава найпоширеніший вид забезпечення виконання зобов'язання. яким був представлений інститут зобов'язального права [22, с.61]. Оскільки кредитор не завжди був впевнений у зобов'язаній особі (iі місці проживання, майновій спроможності), у Цивільному кодексі Східної Галичини 1797 р. була присвячена окрема глава способам забезпечення прав і обов'язків.

Поруку, заставу, завдаток було віднесено до таких способів [25, с. $488-$ 499]. Із загального цивільного уложення Австрійської імперії 1811 p. (ст. 1342-1374) у цьому кодифікованому документі відображаються основні правила забезпечення прав i обов'язків [26], яке на території Галичини i Закарпаття діяло тривалий час. Терміном «зарука» позначався завдаток у цивільному праві Австрії. «Зарука - зумовлене заручним листом грошове забезпечення на випадок невиконання однією зі сторін укладеного договору», так визначається це слово тільки у словнику юридичних термінів у «Зібранні малоросійських прав» (1807р.), які вийшли на момент упорядкування зібрання з ужитку [27, с. 347]. Про звільнення від зобов'язання через повернення завдатку по-різному вирішується питання: «Коли не сповнено договору із-за вини одної сторони, то невинна сторона може задержати сю заруку, яку дістала, або жадати звороту подвійної квоти тої заруки, яку дала, але якщо вона не схоче тим вдоволитися, то може домагатися сповнення, або коли воно неможливе, зворотної шкоди». Звільнити боржника від виконання договірного обов'язку після отримання подвійної суми завдатку може сторона, інтереси якої були порушені. Отже, на розгляд сторін залишилось питання про виконання зобов'язання. Треба звернути увагу, що у наступному параграфі слідом за зарукою обумовлюється відступне «... коли дано заруку, та вимовлено при тім право відступлення, не означуючи 3 осібна відступного, то зарука заступатиме місце відступного. Значить, при відступленні той, хто дав заруку, тратить іiі, або той хто прийняв заруку, звертає іiі подвійно» [28, с. 376, 378]. Підстави для висновку, що тогочасний законодавець передбачив, що завдаток може набувати значення відступного, дав аналіз змісту цього кодифікованого акту. Право Гетьманщини посідає особливе місце в розвитку зобов'язального права України в XVII-XVIII ст., яке на той час регулювалося нормами кодексу 
«Права, за якими судиться малоросійський народ» 1743 р. (далі - «Права»). На розвитку товарно-грошових відносин у тогочасній Гетьманщині позначилося те, що у «Правах» були детально регламентовані положення, які стосувалися укладення договорів купівлі-продажу, обміну, позики, особистого і майнового найму, поклажі, поруки, зберігання. Завдаток, застава і порука були правовим способом захисту зобов'язань від імовірних порушень за такими договорами [29, с. 59]. Завдатком визнавалася грошова сума або інша цінна річ, яку в момент укладення договору одна сторона - боржник (найчастіше покупець) давав другій стороні - кредитору (продавцю). «Хто при купівлі згодиться 3 покупцем відносно ціни речі, але закінчення договору відкладе на пізніший час та відійде, вже не має права вимагати від покупця сторгованої речі, якщо покупець продасть їі іншому, хто не тільки сторгується за ціну, але й за ціну заплатить; так само, хто б сторгував річ і в забезпечення договору дав покупцеві завдаток, або й без завдатку залишив сторговану річ у покупця, а сплату ціни іiі відтягнув аж до кінця ярмарку чи торгу, то покупець, щоб не зазнати втрати, мав право продати річ іншому, а як не продасть, то має право завдаток залишити собі або ж вимагати, щоб покупець куплену річ прийняв i ціну іiі заплатив», це було зазначено у «Правах». В суму сплати платежу (ціну) відповідно до зобов'язання зараховувався завдаток за умови виконання зобов'язання [30, с. 25-28]. Закріплено правила виконання зобов'язання за договорами купівлі-продажу речі та наслідки порушення таких зобов'язань у «Правах» та визначено, що завдаток використовувався в торговельних відносинах між особами під час проведення ярмарків або ж торгів конкретного розміру завдатку, який буде враховуватися до його ціни за умови виконання. Правовий акт не встановлював, а лише вказував стосовно цього питання на взаємну згоду сторін. У сімейних відносинах у значенні весільного дарунка, «Права, за якими судиться малоросійський народ» 1743 р. - єдиний історичний документ, який закріпив положення щодо можливості застосування завдатку. Ні в «Руській правді», ні в Литовських статутах, ні в зведенні законів «Права, за якими судиться малоросійський народ» 1743 р., у тогочасному українському законодавстві норми про завдаток як про окремий правовий субінститут зобов’язального права не були сформовані, а лише окремі договірні відносини, забезпечені завдатком регулювалися зазначеними актами.

Про укладання договору про завдаток у письмовій формі не передбачалось обов'язковим, хоча потреба у його застосуванні завжди існувала. У «Зібранні малоросійських прав» (1807р.) завдаток був закріплений у першій половині XIX ст. в Україні, яка входила до складу Російської імперії, [31, c. 885-1024], в якому було підтвердження факту передачі завдатку завдяки можливості складення контрагентами завдаткової розписки. Виникало право відшкодування збитків, через яке можна простежити компенсаційну функцію завдатку, якщо була складена така розписка та відбулося неукладення договору купівлі-продажу. 3 цього приводу цивілісти Д. Мейєр та Г. Ф. Шершеневич 
вказували на те, що сторони мали право перед укладенням договору купівліпродажу або договору запродажу, який передував йому, забезпечити їх завдатком, про одержання якого продавець видавав покупцю завдаткову розписку, складену в простій письмовій формі. Ця розписка мала містити в собi:

1) вказівку на час iï видачі;

2) визначення умов договору (купівлі-продажу або запродажу), який забезпечувався завдатком;

3) розмір отриманого завдатку;

4) визначення строку, упродовж якого сторони зобов'язувались укласти договір і який не мав перевищувати один рік.

Якщо договір не було укладено 3 причин, що не залежали від контрагентів, завдаток повертався назад. У тогочасному законодавстві зафіксовано обставини, які передбачали врахування вини. Якщо договір не був укладений 3 вини сторони, котра мала стати покупцем, то вона втрачала виданий нею завдаток. Якщо від укладення договору відмовлялась сторона, котра мала стати продавцем, то вона зобов'язувалась повернути отриманий завдаток у подвійному розмірі [2, с. 291-293]. Дослідження положень вищенаведеного нормативного документа свідчать, що метою застосування завдатку було не забезпечення договору, а наділення завдатку особливими рисами, за наявності яких він перетворювався на захід відповідальності. Відповідно до спеціальних норм завдаток використовувався для забезпечення зобов'язань 3 передачі майна у власність, наприклад, договору купівлі-продажу (статті 1494, 1495, 1513 та інші) та запродажу (статті 1681, 1685, 1686 та інші), як зауважує О. С. Блажівська, та не належав до загальних способів забезпечення виконання зобов'язання [34, с. 325]. Норми про завдаток, які набули поширення у вітчизняній правовій системі й нині штучно стримують ініціативу учасників цивільних відносин щодо застосування завдатку 3 метою реалізації не всіх, а лише окремих з його функцій, зазначене підтверджує необхідність певного коригування тих підходів до тлумачення та неймовірний потенціал завдатку. Можна замислитися про доцільність урізноманітнення форм правочинів про завдаток у сучасному правовому контексті. Поряд із неустойкою та правом притримання завдаток був закріплений вже як спосіб забезпечення зобов'язання у Цивільному Уложенні Російської імперії (1905р.) [36]. На призупинення виконання зобов'язання для захисту своїх прав та інтересів за договором набуло законодавчого встановлення право кредитора [33, с. 111].

Аналізуючи ст.1593 Цивільного Уложення Російської імперії, зауважимо, що на підтвердження укладання договору та забезпечення його виконання існувала грошова сума, що видавалася однією стороною другій стороні за умови, якщо вони домовились, і визнавалася завдатком. Умова, що була закріплена у даному документі, вимагала: якщо з вини особи, яка дала завдаток, договір невиконаний, то вона його втрачає, а якщо з вини особи, яка отримала 
завдаток, договір не виконаний, завдаток повертається у повному розмірі та 3 винагородою у розмірі, який перевищує завдаток. Приходимо до висновку при порівнянні з нормами ст. 570, 571 чинного ЦК України, що 3 тих часів і до сьогодення правовий механізм не зазнав значних істотних змін - ані до підстав відповідальності, а ні до умов, а ні до розміру. Коло функцій, які принципово може виконувати завдаток, є також відносно стабільним.

3 різних варіантів західноєвропейського завдатку була змодельована юридична конструкція завдатку, яка зазначалась в проекті Цивільного Уложення. Отже, можемо зробити висновок, що це нова модель завдатку, яка різниться принципово від російського завдатку в XIX ст. [3, с. 27]. Одним 3 видів забезпечення виконання зобов'язань в Україні, як першоджерелом нормативного регулювання завдатку, були звичаї, сформовані упродовж життя українського народу в XIX - на початку XX ст. [37, с. 17].

М.В. Гримич вказує, що договори забезпечувалися за селянським звичаєм, як і за законом, - завдатками, неустойками, заставами, поручительством тощо, відповідно до звичаєвого українського права кінця XIX початку XX ст. Як форма передоплати розглядався завдаток. Були різні санкції проти того, хто порушував угоду: повертав подвійний завдаток той, хто «не встояв на домовленості» на Полтавщині, укладений договір зобов'язувала виконати передача завдатку у Харківській губернії [39, с. 331, 333]. В сучасному цивільному законодавстві набула законодавчого закріплення звичаєва практика застосування завдатку як виду забезпечення виконання зобов'язання [37, с. 17]. 3 метою реалізації превентивної й компенсаційної функцій цивільноправової відповідальності використовувався завдаток.

Грунтується сучасна цивільна нормативно-правова база України переважно на нормах права, які існували в період Радянського Союзу, а тому заслуговує окремої уваги та дослідження застосування завдатку.

Різке скорочення застосування цього способу забезпечення виконання зобов'язання на практиці відбулося за радянських часів, зазначає І.Й. Пучковська [40]. Прийняття 30 січня 1930 р. Постанови ВЦВК і РНК СРСР «Про кредитну реформу» було переломним етапом, який «пригальмував» розвиток завдатку [41], відповідно до якої було заборонено використання завдатку (й авансу) у відносинах між соціалістичними організаціями. Лише аванси за договорами підряду та аванси у формі завдатку в зовнішній торгівлі стали винятками.

Цивільний кодекс РСФСР від 11 червня 1964 р. не встановлював перешкод для використання завдатку у відносинах між громадянами, не мав популярності вказаний спосіб забезпечення виконання зобов'язання, окрім здачі в оренду приміщень та інколи купівлі будинків, до таких висновків прийшов О. С. Йоффе, досліджуючи радянський період розвитку завдатку. У відносинах між громадянами та організаціями завдаток практично не застосовувався. За нинішніх умов розвитку правової й економічної систем України 
варто замислитися й над можливостями, які завдаток здатен надати сторонам зовнішньоекономічних договорів.

В умовах ринкової економіки негативний вплив на застосування завдатку здатні чинити необгрунтовані міркуваннями справедливості, розумності й добросовісності обмеження, які випливають 3 прагнення судів до обмежувального тлумачення чинних норм про завдаток.

Завдаткова розписка, відповідно до якої передавався завдаток, з огляду на історично-правовий аналіз, свідчить про те, що вона не забезпечувала договори, які укладалися в майбутньому, проте була передбачена можливість укладення попереднього договору до моменту укладення договору купівліпродажу як договору запродажу, в якому визначалися умови укладення майбутнього договору купівлі-продажу у вказаний строк за відповідну ціну. Проаналізувавши усю інформацію відносно договору завдатку, прийшли до висновку щодо створення законодавчих передумов для відновлення можливості забезпечення укладання договорів купівлі-продажу нерухомого майна в майбутньому або безпосередньо через нього. Варто доповнити чинне законодавство нормою щодо можливості застосування спеціального способу для забезпечення виконання попереднього договору забезпечувальним платежем, визначивши його як грошову суму 3 вказівкою про обов'язок сторін у майбутньому укласти договір купівлі-продажу на умовах, у строк та за ціну, визначених попереднім договором, оскільки враховуємо, що в ЦК України не обмежено перелік видів забезпечення виконання зобов’язання.

\section{Література}

1. Римскоечастное право: ученик / Под ред. И.Б. Новицкого, И.С. Перетерского. М.: Волтерс Клувер, 2010. 596 с.; 2. Шершеневич Г.Ф. Учебник русского гражданского права. М.: Фирма «СПАРК», 1995. 556 с.; 3. Куликов Е. С. Соглашение о задатке в гражданском праве России: монография. М.: Волтерс Клувер, 2011. 208 с.; 4. Ермошкина М.Ф. Задаток: понятие, правовая квалификация, отдельные виды и сферы применения: автореф. дисс. ... канд. юрид. наук: 12.00.03. М., 2006. 32 с.; 5. Дювернуа Н.Л. Пособие к лекциям по гражданскому праву. Вып. 2: Обязательства. Часть общая: в связи с замечаниями на проект Кн. Гражданского уложения. С.-Петербург, 1901. 392 с.; 6. Орленко В.I. Історія держави і права зарубіжних країн: посіб. для підготов до іспитів, 3-є вид. стереотип. К.: Вид. ПАЛИВОДА А. В., 2008. 244 с.; 7. Лунц Л.А., Новицкий И.Б. Общееучение об обязательстве. М.: Госюриздат, 1950. 416 с.; 8. Zimmermann R. The Law of Obligations Roman Foundations of the Civilian Traditions. New York, 1996. 1241 p.; 9. Азімов Ч.Н. Забезпечення виконання зобов'язань: навч. посібник. Х.: Нац. юрид. акад. Укр., 1995. 48 с.; 10. Брагинский М.И., Витрянский В.В. Договорное право. Кн. 1. Общие положения: М.: Статут, 2005. 1773 с.; 11. Гонгало Б.М. Обеспечение исполнения обязательств. М.: Спарк, 1999. 152 с.; 12. Иоффе О.С., Мусин В. А. Основы римского гражданского права. Ленинград: Из-во Ленинградского ун-та, 1975. 156 с.; 13. Смельянова Л.В. Система забезпечення зобов'язань у римському праві: автореф. дис. ... канд. юрид. наук: 12.00.01. О., 2001. 20 с.; 14. Підопригора О.А., Харитонов Є.О. Римське право: підручник. К.: Юрінком Інтер, 2003. 512 с.; 15. Дигесты Юстиниана. Избранные фрагменты в пер. и с прим. И. С. Перетерского / Отв. 
ред.: Е.А. Скрипилев; Редкол.: В.М. Корецкий, В.С. Нерсесянц, Е.А. Скрипилев, Е.М. Штаерман. М.: Наука, 1984. 456 с.; 16. Шилохвост О.Ю. Отступное в гражданском праве России. М.: Статут, 1999. 251 с.; 17. Пухан И., Поленак-Акимовская М. Римское право: Пер. с македонського / Под ред. В.А. Томсинова М.: Зерцало, 1999. 448 с.; 18. Полдников Д.Ю. Задаток в частном праве (история и современность). Нотариус. 2006. № 3. С. 30-37; 19. Анненков К.Н. Система русского гражданского права. Права обязательственные. Т. 3. 2-е изд., пересмотр. и доп. С.-Петербург: Тип. М. М. Стасюлевича, 1901. 495 с.; 20. Бойко А. Историко-правовые аспекты происхождения и развития института задатка как способа обеспечения исполнения договорных обязательств. Закон и жизнь: международный научно-практический правовой журнал. Молдавия. 2013. № 8/1 (260). С. 50-54; 21. Правдаруська. Текстинаоснові 7 списків та 5 редакцій. Склав та підготував до друку проф. С. В. Юшков. К.: ВУАН, 1935. С. 137-144. URL: http://litopys.org.ua/oldukr2/oldukr51.htm (дата звернення: 12.10.2012); 22. Захарченко П.П. Історія держави та права України: навч. посіб. для дист. навч. К.: Університет «Україна», 2005. 208 с.; 23. Попович О.С. Правові засади і особливості самоврядування вірменських громад на українських землях у складі Польщі та Речі Посполитої (1349-1795 рр.): автореф. дис. ... канд. юрид. наук: 12.00.01. Л., 2010. 20 с.; 24. Пленюк М.Д. Юридичні факти як підстави виникнення цивільноправових зобов'язань (теоретичні та практичні засади): дис. ... док-ра юрид. наук: 12.00.03. К., 2017. 426 с.; 25. Гражданский кодекс Восточной Галиции 1797 г. / Под ред. О.Д. Кутателадзе, В.М. Зубаря. О.: Статут, 2013. 536 с.; 26. Общее гражданское уложение Австрийской империи; пер. Г. Вербловского; издание Редакционной Комиссии по составлению Гражданского Уложения. С.-Петербургъ: Типография Правительствующего Сената, 1884. 421 с.; 27. Собрание малороссийских прав 1807 г. Укладачі: К.А. Вислобоков, А.П. Ткач, І.Б. Усенко, В.А. Чехович. К.: Наукова думка, 1993. 368 с.; 28. Дністрянський С.С. Цивільне право. Відень, 1919. 1063 с.; 29. Піддубний А., Таненок О. Зобов'язальне право України в 17-18 століттях. Персонал. 2006. № 1. С. 59-61; 30. Бойко І.Й. Зобов'язальне право Гетьманщини за «Правами, за якими судиться малоросійський народ» 1743 р. Л.: Світ, 1998. 52 с.; 31. Білоусов Ю.В., Калаур І.Р., Гринько С.Д. та ін. Кодифікація цивільного законодавства на українських землях: у 2 т.; за ред. Р.О. Стефанчука та М.О. Стефанчука. К.: Правоваєдність, 2009. Т. 1. 1168 с.; 32. Білоусов Ю.В., Калаур І.Р., Гринько С.Д. та ін. Кодифікація цивільного законодавства на українських землях у 2 т.; за ред. Р.О. Стефанчука та М.О. Стефанчука. К.: Правоваєдність, 2009. Т. 2. 1240 с.; 33. Гринько Р.В. Історія становлення та розвитку інституту зобов'язального права в Україні. Університетські наукові записки. 2015. № 2 (54). С. 109-117; 34. Блажівська О.С. Історія кодифікацій цивільного законодавства на українських землях (1797-1991 роки): монографія. Кам’янець-Подільський: Друкарня «Рута», 2014. 576 с.; 35. Исаченко В.В. О задатке. Юридический вестник. Издание Московского юридического общества. 1881. № 9. С. 125-168; 36. Проект Гражданского Уложения Российской империи 1905 г. URL: http://constitutions.ru/ ?p=4930 (дата звернення: 12.10.2012); 37. Яворська О. Особливості застосування завдатку у договорах купівлі-продажу нерухомого майна. Право України. 2008. № 8. С. 16-20; 38. Кудінова А. Г. Наукові записки Вінницького державного педагогічного університету імені Михайла Коцюбинського. Серія: Історія. 2015. Вип. 23. С. 196-200; 39. Гримич М.В. Звичаєве цивільне право українців XIX - початку XX століття. К.: Арістей, 2006. 560 с.; 40. Пучковська I. Й. Науково-правовий висновок: чи припиняє сплата завдатку порушене зобов’язання? Науково-практичний журнал «Мала енциклопедія нотаріуса». 2007. №3 (33). URL: http://www.yurradnik.com.ua/club/club.php?action=4\&id=13 (дата звернення: 05.11.2011); 41. Постановление ВЦИК и СНК СССР «О кредитной реформе» от 30.01.1930 г. URL: http://www.libussr.ru/doc_ussr/ussr_3620.htm (дата звернення: 01.11.2011); 42. Иоффе О.С. Обязательственное право. М.: «Юрид. лит.», 1975. 880 с. 